\title{
Characterization of Watermelon (Citrullus lanatus var. citroides) Germplasm for Resistance to Root-knot Nematodes
}

\author{
Judy A. Thies ${ }^{1,3}$ and Amnon Levi ${ }^{2}$ \\ United States Vegetable Laboratory, USDA, ARS, 2700 Savannah Highway, \\ Charleston, SC 29414-5334
}

Additional index words. Citrullus lanatus var. citroides, Citrullus colocynthis, Citrullus lanatus var. lanatus, Meloidogyne arenaria, Meloidogyne incognita, nematode resistance, root-knot nematode

\begin{abstract}
Root-knot nematodes (Meloidogyne spp.) cause extensive damage to watermelon [Citrullus lanatus (Thunb.) Matsum. \& Nakai var. lanatus], and resistance to rootknot nematodes has not been identified in any watermelon cultivar. Twenty-six U.S. Plant Introductions (PIs) of Citrullus lanatus (Thunb.) Matsum. \& Nakai var. citroides (L. H. Bailey) Mansf., one PI of C. lanatus var. lanatus, and three PIs of Citrullus colocynthis $(\mathbf{L}$.) Schrad. were evaluated in greenhouse tests for resistances to Meloidogyne incognita (Kofoid \& White) Chitwood race 3 and Meloidogyne arenaria (Neal) Chitwood race 2. Twenty-three of the $C$. lanatus var. citroides PIs and the $C$. lanatus var. lanatus PIs were previously identified as moderately resistant to $M$. arenaria race 1 . Overall, the C. lanatus var. citroides PIs exhibited low to moderate resistance, and the C. lanatus var. lanatus and $C$. colocynthis PIs were susceptible to both $M$. incognita race 3 and $M$. arenaria race 2 . The $C$. lanatus var. citroides PI 482303 was the most resistant PI with gall index $(\mathrm{GI})=\mathbf{2 . 8 8}$ and reproductive index $(\mathrm{RI})=\mathbf{0 . 3 4}$ for $M$. incognita race 3 and $\mathrm{GI}=$ 3.46 and $\mathrm{RI}=0.38$ for $M$. arenaria race $2(1=$ no galling; $5=26 \%$ to $38 \%$ root system galled; $9=81 \%$ to $100 \%$ root system galled). These results demonstrate that there is significant genetic variability within $C$. lanatus var. citroides for reaction to $M$. incognita and $M$. arenaria race 2 , and several $C$. lanatus var. citroides PIs may provide sources of resistance to root-knot nematodes.
\end{abstract}

Watermelon (C. lanatus var. lanatus) is an important vegetable crop grown in the United States with an annual production of 2.1 million tons and a farm value of \$435 million (U.S. Department of Agriculture [USDA], 2007). Root-knot nematodes (Meloidogyne spp.) cause extensive damage to watermelon throughout the southern United States (Sumner and Johnson, 1973; Thies, 1996; Thomason and McKinney, 1959; Winstead and Riggs, 1959) and increase the severity of Fusarium wilt in watermelon fields (Sumner and Johnson, 1973).

Root-knot nematodes are primarily controlled in watermelon by fumigation with methyl bromide. Approximately $6 \%$ of all

\footnotetext{
Received for publication 15 Mar. 2006. Accepted for publication 2 June 2006.

We thank S. Merrill, R. Reeves, P. Berland, and W. Cook for technical assistance in conducting the experiments.

Mention of a trademark, proprietary product, or vendor does not constitute a guarantee or warranty of the product by the U.S. Department of Agriculture and does not imply its approval to the exclusion of other products or vendors that also may be suitable.

${ }^{1}$ Research Plant Pathologist.

${ }^{2}$ Research Geneticist.

${ }^{3}$ To whom reprint requests should be addressed; e-mail judy.thies@ars.usda.gov.
}

methyl bromide treatments in vegetable crops throughout the world are for watermelon and melon (Cucumis melo L.) (USDA, 1993). However, use of methyl bromide is being phased out in the United States (U.S. Environmental Protection Agency, 2000). The loss of methyl bromide for preplant soil fumigation was predicted to result in annual yield losses of $15 \%$ to $20 \%$ for watermelon in Georgia and Florida (Lynch and Carpenter, 1999). The removal of methyl bromide from the U.S. market has raised great interest in developing an alternative approach for managing rootknot nematodes in vegetable crops. Host plant resistance would provide an economical and environmentally friendly alternative for managing root-knot nematodes in watermelon.

There are several reports describing the reactions of cultivated watermelon to rootknot nematodes. Seventy-eight watermelon cultivars and five breeding lines evaluated for response to root-knot nematode were all susceptible (Winstead and Riggs, 1959). Similarly, 10 watermelon cultivars evaluated in Puerto Rico were all susceptible to M. incognita (Montalvo and Esnard, 1994). Thomason and McKinney (1959) reported that the watermelon cultivar 'Striped Klondike' was susceptible to $M$. incognita acrita and M. javanica.

In a recent study, we optimized a procedure for evaluating U.S. PIs of Citrullus spp. for resistance to root-knot nematodes
(Thies and Levi, 2003). In that study, moderate resistance to $M$. arenaria race 1 was identified among $C$. lanatus var. citroides PIs. The objective of this study was to evaluate the group of $C$. lanatus var. citroides PIs that showed moderate resistance to $M$. arenaria race 1 for resistances to $M$. incognita race 3 and $M$. arenaria race 2 .

\section{Materials and Methods}

Inocula. Meloidogyne incognita race 3 and $M$. arenaria race 2 were cultured on 'Kentucky Wonder 191' pole bean (Phaseolus vulgaris L.) and 'Rutgers' tomato (Lycopersicon esculentum Mill.) in the greenhouse. Egg inocula were extracted from bean and tomato roots using $0.5 \%$ sodium hypochlorite (Hussey and Barker, 1973).

Plant material. Twenty-six accessions of C. lanatus var. citroides, one accession of C. lanatus var. lanatus, and three accessions of $C$. colocynthis from the U.S. PI Citrullus germplasm collection were evaluated for resistance to $M$. incognita race 3 and $M$. arenaria race 2 in replicated greenhouse tests. The accessions were selected based on their reactions (both resistant and susceptible) to M. arenaria race 1 in previous greenhouse studies (Thies and Levi, 2003). 'Charleston Gray', 'Crimson Sweet', and 'Dixie Lee' $(C$. lanatus var. lanatus) were included as susceptible reference control cultivars in all tests.

Meloidogyne incognita tests 1 and 2. Thirty Citrullus spp. accessions and three watermelon control cultivars were evaluated for resistance to $M$. incognita in two greenhouse tests. The experimental design was a randomized complete block with 33 watermelon genotypes $\times$ four replicates $\times$ five plants per replicate $(n=20)$ in the first test and three replicates $\times$ five plants per replicate $(\mathrm{n}=15)$ in the second test.

Meloidogyne arenaria race 2 tests 1 and 2 . Thirty Citrullus spp. accessions and three watermelon control cultivars were evaluated for resistance to $M$. arenaria race 2 in two greenhouse tests. The experimental design, numbers of replicates, and numbers of plants per replicate for the $M$. arenaria race 2 tests were the same as for the $M$. incognita tests, previously described.

Greenhouse evaluation procedures. The seeds were sown in plastic trays containing 50 individual $0.2-\mathrm{L}$ cells filled with Metro-Mix 360 (The Scotts Company, Marysville, OH) and placed in a greenhouse maintained between $26{ }^{\circ} \mathrm{C}$ and $31{ }^{\circ} \mathrm{C}$. When seedlings were at the first true leaf stage, $3 \mathrm{~mL}$ distilled water containing $\approx 2500$ eggs of either $M$. incognita race 3 or $M$. arenaria race 2 were pipetted into the rhizosphere soil of each plant at a $1-\mathrm{cm}$ depth. Plants were fertilized 2 and 5 weeks after sowing with one-half strength 20N-20P-16K water-soluble fertilizer (Peter's Fertilizer; United Industries Corp., St. Louis). Eight weeks later, the shoots of all plants were clipped at the crown, and the roots were removed from each cell and carefully washed. The root systems of each plant were then submerged in a 15\% solution of McCormick's 
red food color (Thies et al., 2002) for 15 to 20 min to stain the egg masses. The root systems were carefully rinsed under running tap water and evaluated for galling severity and egg mass production using a 1 to 9 scale in which $1=0,2=1 \%$ to $3 \%, 3=4 \%$ to $12 \%, 4=13 \%$ to $25 \%, 5=26 \%$ to $38 \%, 6=39 \%$ to $50 \%, 7=$ $51 \%$ to $65 \%, 8=66 \%$ to $80 \%$, and $9=81 \%$ to $100 \%$ of root system galled or covered with egg masses, respectively (Thies and Fery, 1998). Ratings were 1 to $2.9=$ high resistance, 3.0 to $4.0=$ moderate resistance, 4.1 to $4.9=$ low resistance, 5.0 to $6.9=$ susceptible; and 7.0 to $9.0=$ highly susceptible (Thies and Levi, 2003). Then, the entire root systems of all plants of each accession in a replicate were cut into 1- to 2-cm pieces, the total root weight was recorded, and root-knot nematode eggs were extracted from the root sample using $1.0 \%$ $\mathrm{NaOCl}$ (Hussey and Barker, 1973). The $0.5 \%$ $\mathrm{NaOCl}$ was used to extract eggs for inoculum to avoid damage to the eggs; however, $1.0 \%$ $\mathrm{NaOCl}$ was used to extract eggs for estimating nematode reproduction because extraction is more efficient with a higher concentration of $\mathrm{NaOCl}$. Numbers of eggs were counted using a stereomicroscope. Nematode reproduction was assessed by calculating the reproductive index (RI) in which $R I=P_{f} / P_{i}$, where $P_{i}=$ the initial inoculum level and $\mathrm{P}_{\mathrm{f}}=$ final egg recovery (Sasser et al., 1984). Eggs per gram fresh root and nematode reproductive index data were $\log _{10}(x+1)$ transformed before analysis. Data were analyzed using the GLM procedure of SAS for Windows, v.8.0 (SAS Institute, Cary, NC), and means were separated using Fisher's protected least significant difference test.

\section{Results and Discussion}

Overall, the C. lanatus var. citroides PI exhibited higher resistance to $M$. incognita and $M$. arenaria race 2 than the watermelon cultivars and $C$. colocynthis $\mathrm{PI}$. The $C$. lanatus var. citroides root systems exhibited minimal to moderate galling; the root systems were more fibrous and had fewer and smaller galls than the root systems of the watermelon cultivars and the $C$. colocynthis PIs (Tables 1 and 2). Like in a previous study with $M$. arenaria race 1 (Thies and Levi, 2003), all three PIs of the desert species $C$. colocynthis also were highly susceptible to $M$. incognita race 3 and $M$. arenaria race 2 (Tables 1 and 2).

Meloidogyne incognita race 3 tests 1 and 2. The C. lanatus var. citroides PI 482303 exhibited high resistance in both tests with $M$. incognita race 3; gall index (GI) was 2.80 and $\mathrm{GI}=2.97$ in tests 1 and 2, respectively, with $1535 \mathrm{M}$. incognita eggs per gram fresh root and $\mathrm{RI}=0.34$ (Table 1). An additional 21 C. lanatus var. citroides PIs exhibited low to moderate resistance to $M$. incognita race 3 based on root gall severity (GI ranges: 3.07 to 4.80 in test 1 and 3.00 to 4.25 in test 2 ). However, some of these PIs had relatively high numbers of eggs per $\mathrm{g}$ fresh root (greater than 5000) and RIs greater than 1.0 (Table 1). For example, PI 189225 supported 16,508 eggs of $M$. incognita per gram fresh root and $\mathrm{RI}=2.17$. The PIs 248774, 288316, and 532666 exhibited susceptible reactions to $M$. arenaria race 1 in previous tests (Thies and Levi, 2003) and were also susceptible to $M$. incognita race 3 in the current tests (Table 1). The PI 542114 exhibited low resistance to $M$. arenaria race 1 in a previous

Table 1. Gall indices, egg mass indices, numbers of Meloidogyne incognita race 3 eggs per gram fresh root, and reproductive indices for selected PIs of Citrullus lanatus var. citroides, C. lanatus var. lanatus, and C. colocynthis and control watermelon cultivars inoculated with $M$. incognita race 3 in replicated greenhouse tests. ${ }^{2}$

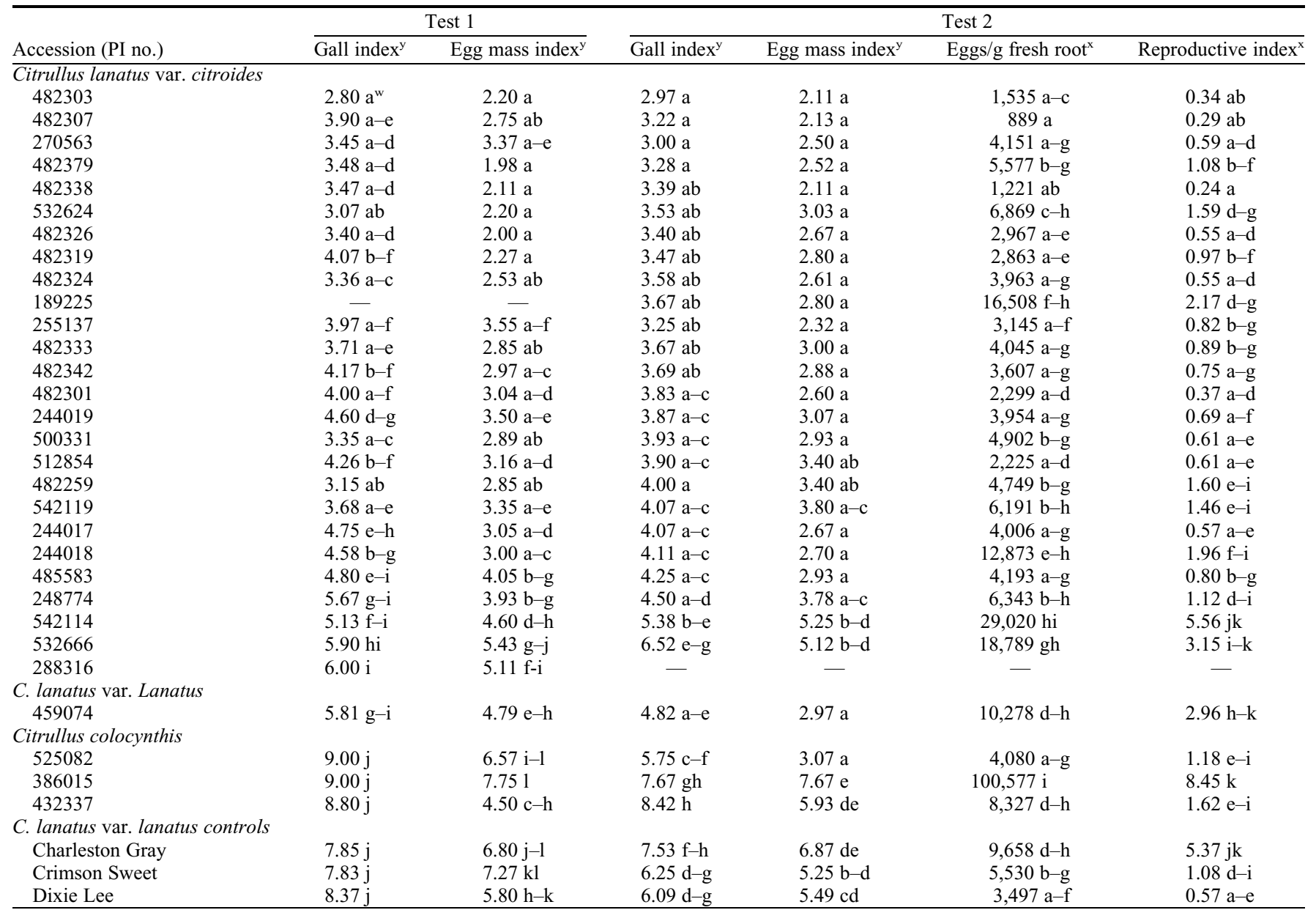

${ }^{2}$ Means of four replicates of five plants per replicate $(\mathrm{n}=20)$ in test 1 and means of three replicates of five plants per replicate $(\mathrm{n}=15)$ in test 2 .

${ }^{\mathrm{y}} 1$ to 9 scale in which $1=$ no galling or visible egg masses present, $2=1 \%$ to $3 \%, 3=4 \%$ to $10 \%, 4=11 \%$ to $25 \%, 5=26 \%$ to $35 \%, 6=36 \%$ to $50 \%, 7=51 \%$ to $65 \%, 8=66 \%$ to $80 \%$, and $9=81 \%$ to $100 \%$ of root system galled or covered with egg masses, respectively.

${ }^{\mathrm{x}}$ Data were $\log _{10}(\mathrm{x}+1)$ transformed before analysis. Nontransformed data are shown.

${ }^{w}$ Mean separation within columns by Fisher's protected least significant difference test, $P \leq 0.05$. 
Table 2. Gall indices, egg mass indices, numbers of Meloidogyne arenaria race 2 eggs per gram fresh root, and reproductive indices for selected PIs of Citrullus lanatus var. citroides, C. lanatus var. lanatus, and C. colocynthis and control watermelon cultivars inoculated with $M$. arenaria race 2 in replicated greenhouse tests. ${ }^{\mathrm{z}}$

\begin{tabular}{|c|c|c|c|c|c|c|}
\hline \multirow[b]{2}{*}{ Accession (PI no.) } & \multicolumn{2}{|c|}{ Test 1} & \multicolumn{4}{|c|}{ Test 2} \\
\hline & Gall index ${ }^{y}$ & Egg mass index ${ }^{y}$ & Gall index ${ }^{y}$ & Egg mass index ${ }^{y}$ & Eggs/g fresh root ${ }^{x}$ & Reproductive index $^{x}$ \\
\hline \multicolumn{7}{|c|}{ Citrullus lanatus var. citroides } \\
\hline 482303 & $3.70 \mathrm{a}^{\mathrm{w}}$ & $3.18 \mathrm{a}$ & $3.22 \mathrm{a}-\mathrm{c}$ & $2.18 \mathrm{ab}$ & $2,633 \mathrm{~d}-\mathrm{k}$ & $0.38 \mathrm{c}-\mathrm{j}$ \\
\hline 482307 & $5.28 \mathrm{a}-\mathrm{e}$ & $3.49 \mathrm{a}$ & $3.15 \mathrm{a}-\mathrm{c}$ & $1.73 \mathrm{ab}$ & $209 a-c$ & $0.04 \mathrm{a}-\mathrm{c}$ \\
\hline 270563 & $5.37 \mathrm{a}-\mathrm{e}$ & $3.75 \mathrm{a}$ & $4.50 \mathrm{c}-\mathrm{e}$ & $2.11 \mathrm{ab}$ & $547 \mathrm{a}-\mathrm{f}$ & $0.08 \mathrm{a}-\mathrm{e}$ \\
\hline 482379 & $5.38 \mathrm{a}-\mathrm{e}$ & $3.35 \mathrm{a}$ & $3.17 \mathrm{a}-\mathrm{c}$ & $2.22 \mathrm{ab}$ & $1,463 \mathrm{c}-\mathrm{i}$ & $0.24 \mathrm{c}-\mathrm{h}$ \\
\hline 482338 & $4.20 \mathrm{ab}$ & $3.100 \mathrm{a}$ & $3.08 \mathrm{a}-\mathrm{c}$ & $2.00 \mathrm{ab}$ & $689 \mathrm{a}-\mathrm{g}$ & $0.12 \mathrm{~b}-\mathrm{e}$ \\
\hline 532624 & $5.73 \mathrm{a}-\mathrm{e}$ & $4.07 \mathrm{a}-\mathrm{c}$ & $3.02 \mathrm{a}-\mathrm{c}$ & $1.96 \mathrm{ab}$ & $254 \mathrm{a}-\mathrm{d}$ & $0.04 \mathrm{a}-\mathrm{c}$ \\
\hline 482326 & $4.76 \mathrm{a}-\mathrm{d}$ & $3.54 \mathrm{a}$ & $3.13 \mathrm{a}-\mathrm{c}$ & $2.07 \mathrm{ab}$ & $535 \mathrm{a}-\mathrm{f}$ & $0.08 \mathrm{a}-\mathrm{d}$ \\
\hline 482319 & $4.28 \mathrm{ab}$ & $3.35 \mathrm{a}$ & $2.78 \mathrm{ab}$ & $1.55 \mathrm{ab}$ & $106 \mathrm{ab}$ & $0.02 \mathrm{ab}$ \\
\hline 482324 & $5.45 \mathrm{a}-\mathrm{e}$ & $4.10 \mathrm{a}-\mathrm{c}$ & $2.50 \mathrm{ab}$ & $2.00 \mathrm{ab}$ & $262 \mathrm{a}-\mathrm{e}$ & $0.02 \mathrm{ab}$ \\
\hline 189225 & - & - & $2.40 \mathrm{ab}$ & $1.40 \mathrm{a}$ & $81 \mathrm{a}$ & $0.01 \mathrm{a}$ \\
\hline 255137 & $4.67 \mathrm{a}-\mathrm{c}$ & $3.33 \mathrm{a}$ & $3.11 \mathrm{a}-\mathrm{c}$ & $2.61 \mathrm{ab}$ & $4,320 \mathrm{f}-\mathrm{k}$ & $0.64 \mathrm{~d}-\mathrm{j}$ \\
\hline 482333 & $5.76 \mathrm{a}-\mathrm{e}$ & $4.18 \mathrm{a}-\mathrm{c}$ & $3.33 \mathrm{a}-\mathrm{c}$ & $2.17 \mathrm{ab}$ & $4,979 \mathrm{f}-\mathrm{k}$ & $0.62 \mathrm{~d}-\mathrm{j}$ \\
\hline 482342 & $5.25 \mathrm{a}-\mathrm{e}$ & $3.63 \mathrm{a}$ & $2.73 \mathrm{ab}$ & $1.82 \mathrm{ab}$ & $1,567 \mathrm{c}-\mathrm{j}$ & $0.24 \mathrm{c}-\mathrm{g}$ \\
\hline 482301 & $5.40 \mathrm{a}-\mathrm{e}$ & $3.67 \mathrm{a}$ & $3.33 \mathrm{a}-\mathrm{c}$ & $1.80 \mathrm{ab}$ & $2,158 \mathrm{c}-\mathrm{k}$ & $0.34 \mathrm{c}-\mathrm{j}$ \\
\hline 244019 & $5.30 \mathrm{a}-\mathrm{e}$ & $4.17 \mathrm{a}-\mathrm{c}$ & $3.33 \mathrm{a}-\mathrm{c}$ & $2.47 \mathrm{ab}$ & $3,054 \mathrm{f}-\mathrm{k}$ & $0.38 \mathrm{c}-\mathrm{j}$ \\
\hline 500331 & $6.25 \mathrm{a}-\mathrm{f}$ & $4.40 \mathrm{a}-\mathrm{d}$ & $2.28 \mathrm{a}$ & $1.50 \mathrm{a}$ & $990 \mathrm{~b}-\mathrm{h}$ & $0.20 \mathrm{c}-\mathrm{g}$ \\
\hline 512854 & $7.13 \mathrm{c}-\mathrm{g}$ & $5.30 \mathrm{a}-\mathrm{e}$ & $3.22 \mathrm{a}-\mathrm{c}$ & $2.58 \mathrm{ab}$ & $1,791 \mathrm{c}-\mathrm{j}$ & $0.34 \mathrm{c}-\mathrm{i}$ \\
\hline 482259 & $4.44 \mathrm{ab}$ & $3.74 \mathrm{a}$ & $2.67 \mathrm{ab}$ & $1.87 \mathrm{ab}$ & $775 \mathrm{a}-\mathrm{g}$ & $0.12 \mathrm{~b}-\mathrm{e}$ \\
\hline 542119 & $3.92 \mathrm{ab}$ & $3.70 \mathrm{a}$ & $2.83 \mathrm{ab}$ & $1.50 \mathrm{a}$ & $1,072 \mathrm{~b}-\mathrm{h}$ & $0.17 \mathrm{~b}-\mathrm{f}$ \\
\hline 244017 & $4.75 \mathrm{a}-\mathrm{d}$ & $3.31 \mathrm{a}$ & $3.47 \mathrm{a}-\mathrm{c}$ & $1.73 \mathrm{ab}$ & $1,078 \mathrm{~b}-\mathrm{h}$ & $0.13 \mathrm{~b}-\mathrm{e}$ \\
\hline 244018 & $5.20 \mathrm{a}-\mathrm{e}$ & $3.95 \mathrm{a}-\mathrm{c}$ & $3.89 \mathrm{~b}-\mathrm{d}$ & $2.22 \mathrm{ab}$ & $2,769 \mathrm{e}-\mathrm{k}$ & $0.32 \mathrm{c}-\mathrm{h}$ \\
\hline 485583 & $4.94 \mathrm{a}-\mathrm{d}$ & $3.92 \mathrm{ab}$ & $2.87 \mathrm{ab}$ & $1.27 \mathrm{a}$ & $138 \mathrm{ab}$ & $0.02 \mathrm{ab}$ \\
\hline 248774 & $5.80 \mathrm{a}-\mathrm{e}$ & $3.99 \mathrm{a}-\mathrm{c}$ & $3.75 \mathrm{a}-\mathrm{d}$ & $2.33 \mathrm{ab}$ & $5,311 \mathrm{f}-\mathrm{k}$ & $0.81 \mathrm{e}-\mathrm{j}$ \\
\hline 542114 & $4.98 \mathrm{a}-\mathrm{d}$ & $3.90 \mathrm{a}$ & $3.18 \mathrm{a}-\mathrm{c}$ & $1.72 \mathrm{ab}$ & $2,647 \mathrm{~d}-\mathrm{k}$ & $0.45 \mathrm{~d}-\mathrm{j}$ \\
\hline 532666 & $7.73 \mathrm{e}-\mathrm{g}$ & $6.22 \mathrm{~b}-\mathrm{e}$ & $3.11 \mathrm{a}-\mathrm{c}$ & $1.61 \mathrm{ab}$ & $521 \mathrm{a}-\mathrm{f}$ & $0.05 \mathrm{a}-\mathrm{c}$ \\
\hline 288316 & - & - & $3.00 \mathrm{a}-\mathrm{c}$ & $3.00 \mathrm{bc}$ & $7,254 \mathrm{~g}-\mathrm{k}$ & $0.87 \mathrm{e}-\mathrm{j}$ \\
\hline \multicolumn{7}{|c|}{ Citrullus lanatus var. lanatus } \\
\hline 459074 & $7.20 \mathrm{c}-\mathrm{g}$ & $5.30 \mathrm{a}-\mathrm{e}$ & $2.93 \mathrm{ab}$ & $2.33 \mathrm{ab}$ & $5,013 \mathrm{f}-\mathrm{k}$ & $1.45 \mathrm{f}-\mathrm{j}$ \\
\hline \multicolumn{7}{|l|}{ Citrullus colocynthis } \\
\hline 525082 & $8.65 \mathrm{fg}$ & $6.69 \mathrm{~d}-\mathrm{f}$ & 5.80 ef & $3.02 \mathrm{bc}$ & $8,082 \mathrm{~h}-\mathrm{k}$ & $1.06 \mathrm{e}-\mathrm{j}$ \\
\hline 386015 & $9.00 \mathrm{~g}$ & $8.75 \mathrm{f}$ & $9.00 \mathrm{~h}$ & $8.17 \mathrm{e}$ & $19,665 \mathrm{k}$ & $2.40 \mathrm{ij}$ \\
\hline 432337 & $7.31 \mathrm{~d}-\mathrm{g}$ & 6.94 ef & $7.33 \mathrm{~g}$ & $5.55 \mathrm{~d}$ & $14,438 \mathrm{i}-\mathrm{k}$ & $1.91 \mathrm{~g}-\mathrm{j}$ \\
\hline \multicolumn{7}{|c|}{ Citrullus lanatus var. lanatus controls } \\
\hline Charleston Gray & $7.16 \mathrm{c}-\mathrm{g}$ & 6.94 ef & $7.40 \mathrm{~g}$ & $5.27 \mathrm{~d}$ & $8,592 \mathrm{~h}-\mathrm{k}$ & $2.15 \mathrm{~h}-\mathrm{j}$ \\
\hline Crimson Sweet & $6.40 \mathrm{~b}-\mathrm{f}$ & $6.25 \mathrm{c}-\mathrm{e}$ & $5.17 \mathrm{~d}-\mathrm{f}$ & $2.60 \mathrm{ab}$ & $9,103 \mathrm{~h}-\mathrm{k}$ & $1.77 \mathrm{~g}-\mathrm{j}$ \\
\hline Dixie Lee & $7.60 \mathrm{e}-\mathrm{g}$ & $7.49 \mathrm{ef}$ & $6.67 \mathrm{fg}$ & $4.27 \mathrm{~cd}$ & $15,758 \mathrm{jk}$ & $3.27 \mathrm{j}$ \\
\hline
\end{tabular}

${ }^{\mathrm{z}}$ Means of four replicates of five plants per replicate $(\mathrm{n}=20)$ in test 1 and means of three replicates of five plants per replicate $(\mathrm{n}=15)$ in test 2 .

${ }^{\mathrm{y}} 1$ to 9 scale in which $1=$ no galling or visible egg masses present, $2=1 \%$ to $3 \%, 3=4 \%$ to $10 \%, 4=11 \%$ to $25 \%, 5=26 \%$ to $35 \%, 6=36 \%$ to $50 \%, 7=51 \%$ to $65 \%, 8=66 \%$ to $80 \%$, and $9=81 \%$ to $100 \%$ of root system galled or covered with egg masses, respectively.

${ }^{\mathrm{x}}$ Data were $\log _{10}(\mathrm{x}+1)$ transformed before analysis. Nontransformed data are shown.

'Mean separation within columns by Fisher's protected least significant difference test, $P \leq 0.05$.

unreplicated test (Thies and Levi, 2003), but was moderately susceptible to $M$. incognita in the present studies.

The PI 459074 was the only one of $156 C$. lanatus var. lanatus PIs evaluated that exhibited any resistance to $M$. arenaria race 1 (Thies and Levi, 2003). However, in this study, PI 459074 was susceptible to $M$. incognita race 3 based on both root gall severity and nematode reproduction (Table 1). The three C. lanatus var. lanatus watermelon cultivars ('Crimson Sweet', 'Dixie Lee', and 'Charleston Gray') were also susceptible to $M$. incognita race 3 (Table 1), like in a previous study with $M$. arenaria race 1 (Thies and Levi, 2003). The GIs ranged from 7.85 to 8.37 in test 1 and 6.09 to 7.53 in test 2; numbers of eggs per gram fresh root ranged from 3497 to 9658 and RIs ranged from 0.57 to 5.37. Numbers of eggs per gram fresh root and RIs for 'Crimson Sweet' and 'Dixie Lee' were somewhat lower than expected as a result of a reduction in fibrous root systems associated with root-knot nematode damage.

The three $C$. colocynthis PIs were highly susceptible to $M$. incognita race 3 (Table 1), similar to their reactions to M. arenaria race 1 in prior tests (Thies and Levi, 2003). The root gall severity indices for the C. colocynthis accessions ranged from 8.80 to 9.00 in test 1 and from 5.75 to 8.42 in test 2 ; numbers of eggs per gram fresh root ranged from 4080 to 100,577 and RIs ranged from 1.18 to 8.45 .

Meloidogyne arenaria race 2 tests 1 and 2 . Ten C. lanatus var. citroides accessions (PI 482303, PI 482338, PI 482326, PI 482319, PI 255137, PI 482259, PI 542119, PI 244017 , PI 485583, and PI 542114) exhibited low to moderate resistance to $M$. arenaria race 2 in both tests 1 and 2 (GI ranges: 3.70 to 4.98 in test 1 and 2.67 to 3.47 in test 2; numbers of M. arenaria race 2 eggs per gram fresh root ranged from 106 to 4320 and RIs ranged from 0.02 to 0.64 ) (Table 2).

The C. lanatus var. lanatus PI 459074 was susceptible to $M$. arenaria race 2 in both tests (Table 2). In contrast, this accession (PI 459074) exhibited low resistance to $M$. arenaria race 1 in a previous study (Thies and Levi, 2003). The three C. lanatus var. lanatus watermelon cultivars ('Crimson Sweet', 'Dixie Lee', and 'Charleston Gray') were also sus- ceptible to $M$. arenaria race 2 (GI range: 6.40 to 7.60 for test 1 and 5.17 to 7.40 for test 2; numbers of $M$. arenaria race 2 eggs per gram fresh root ranged from 8592 to 15,758 and RIs ranged from 1.77 to 3.27 ) (Table 2). These three watermelon cultivars were also susceptible to $M$. arenaria race 1 in an earlier study (Thies and Levi, 2003).

The three C. colocynthis PIs were highly susceptible to $M$. arenaria race 2 (Table 2), similar to their reactions to $M$. arenaria race 1 in past tests (Thies and Levi, 2003). The root gall severity indices for the C. colocynthis accessions ranged from 7.31 to 9.00 in test 1 and 5.80 to 9.00 in test 2 ; the numbers of eggs per gram fresh root ranged from 8082 to 19,665 and RIs ranged from 1.06 to 2.40 .

In general, the $C$. lanatus var. citroides PIs exhibited low to moderate resistance to both $M$. incognita race 3 and $M$. arenaria race 2 . The C. lanatus var. citroides PI 482303 was the most resistant with average GIs of 2.88 and 3.46 for $M$. incognita and $M$. arenaria race 2, respectively; RIs were less than 0.40 for both Meloidogyne species. These results demonstrate that there is significant genetic 
variability within $C$. lanatus var. citroides for reaction to $M$. incognita race 3 and $M$. arenaria race 2 , and several $C$. lanatus var. citroides PIs may provide sources of resistance to root-knot nematodes for the development of resistant watermelon cultivars.

\section{Literature Cited}

Hussey, R.S. and K.R. Barker. 1973. A comparison of methods of collecting inocula of Meloidogyne spp., including a new technique. Plant Dis. Rep. 57:1025-1028.

Lynch, L. and J. Carpenter. 1999. The economic impacts of banning methyl bromide: Where do we need more research? 1999 Annual Research Conference on Methyl Bromide Alternatives and Emissions Reductions. 19 Sept. 2007. <www. epa.gov/ozone/mbr/airc/1999/55lynchl.pdf>.

Montalvo, A.E. and J. Esnard. 1994. Reaction of ten cultivars of watermelon (Citrullus lanatus) to a Puerto Rican population of Meloidogyne incognita. J. Nematol. 26(suppl):640-643.

Sasser, J.N., C.C. Carter, and K.M. Hartman. 1984 Standardization of host suitability studies and reporting of resistance to root-knot nematodes. Crop Nematode Resistance Control Project, N.C. State Univ., U.S. Agency for Intl. Dev., Raleigh, NC.

Sumner, D.R. and A.W. Johnson. 1973. Effect of root-knot nematodes on Fusarium wilt of watermelon. Phytopathology 63:857-861.

Thies, J.A. 1996. Diseases caused by nematodes, p. 56-58. In: T.A. Zitter, D.L. Hopkins, and C.E. Thomas (eds.). Compendium of cucurbit diseases. APS Press, St. Paul, MN.

Thies, J.A. and R.L. Fery. 1998. Modified expression of the $N$ gene for southern root-knot nematode resistance in pepper at high soil temperatures. J. Amer. Soc. Hort. Sci. 123:1012-1015.

Thies, J.A. and A. Levi. 2003. Resistance of watermelon germplasm to the peanut root-knot nematode. HortScience 38:1417-1421.
Thies, J.A., S.B. Merrill, and E.L. Corley, Jr. 2002. Red food coloring stain: New, safer procedures for staining nematodes in roots and egg masses on root surfaces. J. Nematol. 34:179-181.

Thomason, I.J. and H.E. McKinney. 1959. Reaction of some Cucurbitaceae to root-knot nematodes (Meloidogyne spp.). Plant Dis. Rep. 43:448-450.

U.S. Department of Agriculture. 1993. USDA workshop on alternatives for methyl bromide. 29 June-1 July 1993. Crystal City, VA.

U.S. Department of Agriculture. 2007. National Agricultural Statistics Service. Vegetables 2006 Summary. p. 33.

U.S. Environmental Protection Agency. 2000. Protection of stratospheric ozone: Incorporation of Clean Air Act amendments for reductions in Class I, Group VI controlled substances. Fed. Reg. 65:70795-70804.

Winstead, N.N. and R.D. Riggs. 1959. Reaction of watermelon varieties to root-knot nematodes. Plant Dis. Rep. 43:909-912. 